Pamiętnik Literacki 2018, 3, s. 126-143

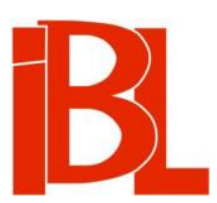

\title{
Krótka historia "O!” (Wokół utworu Julii Hartwig)
}

\author{
Witold Sadowski
}




\title{
Z A G A D N I E I A J E Z Y K A A R T Y S T Y C Z N E G O
}

\author{
Pamiętnik Literacki CIX, 2018, z. 3, PL ISSN 0031-0514
}

DOI: $10.18318 /$ PL.2018.3.9

WITOLD SADOWSKI Uniwersytet Warszawski

\section{KRÓTKA HISTORIA „O!” (WOKÓE UTWORU JULII HARTWIG)*}

Do tomiku Julii Hartwig Chwila postoju z 1980 roku, w którym wiersze przeplatają się z prozą poetycką, autorka włączyła m.in. utwór, który w części późniejszych wydań ${ }^{1}$ otrzymał tytuł $O$ !:

O, białe kwiaty cienia, dziki blasku rzeki! ${ }^{2}$

Przytoczona wypowiedź stanowi całość utworu. Nie ma w nim żadnego dodatkowego zdania. Wszystko zamyka się w ramach jednej linijki druku, zawieszonej samotnie na pustej stronicy i otoczonej z góry i $z$ dołu przytłaczającą bielą niezagospodarowanej przestrzeni.

Dla badacza literatury - a co dopiero dla zwykłego czytelnika - lapidarna forma tekstu jest interpretacyjnym wyzwaniem. Wojciech Ligęza podzielił się następującym doświadczeniem:

Biedzę się, jak zacząc recenzję z Chwili postoju. W końcu napisałem niepewnie tytuł „Poetka milczenia”. Staroświecki zegar nocą wybijał godziny. I ciagle powracało zdanie: „O, białe kwiaty cienia, dziki blasku rzeki!"3

Pierwszy problem, jaki przynosi ten utwór, wiąże się z próbą ulokowania go w polach wersologii. Kontekst tomiku Chwila postoju nie pozwala rozstrzygnać, czy w tekście ograniczającym się do jednej linijki mamy do czynienia $z$ wierszem czy z proza. Sama Hartwig wykonała gest, jak gdyby chciała nam wytraccić $z$ ręki to pytanie. Za jej życia utwór został przedrukowany zarówno w zbiorze Nim opatrzy się zieleń, noszacym podtytuł Wybór wierszy ${ }^{4}$, jak i w zbiorze Mówiąc tylko do siebie z podtytułem Poematy proza ${ }^{5}$. W przekonującej opinii Marcina Telickiego,

* $\quad$ Artykuł powstał w ramach realizacji projektu Wiersz litanijny $w$ kulturze regionów Europy. Projekt został sfinansowany ze środków Narodowego Centrum Nauki przyznanych na podstawie decyzji numer DEC-2012/07/E/HS2/00665.

1 J. H a r tw i g: Mówiac nie tylko do siebie. Poematy proza. Warszawa 2003, s. 35; Poezje wybrane / Selected Poems. Przeł. J. i B. C arpenter. Posł. J. Hartwig, J. i B. C a r pent e r. Kraków 2008, s. 24.

2 J. Hartwig, Chwila postoju. Kraków 1980, s. 10.

3 Słowa W. Li gę zy cytowane za zestawieniem Błyski o Julii Hartwig („Topos” 2004, nr 3/4, s. 31).

4 J. Ha rtwi g, Nim opatrzy się zieleń. Wybór wierszy. Kraków 1995, s. 73.

5 Ha r twig, Mówiac nie tylko do siebie. 
demontowanie przez Hartwig podziałów gatunkowych uwypukla rolę ludzkiego doświadczenia wymierzonego „przeciw tekstowym grom formalnym”. Badacz wszelako rozpatruje to zagadnienie w kontekście genologii. Jeśli natomiast spojrzeć na ten sam problem $z$ punktu widzenia wersologii, wówczas obszar, który jeszcze chwilę temu jawił się jako rozmyty, nabiera nieoczekiwanie ostrości, a przeanalizowanie argumentów za „proza” i za „wierszem” prowadzi nas w końcu do jednoznacznej odpowiedzi. Przejdziemy tę drogę myślową krok po kroku.

Tekst wydaje się nawiązywać do prozy - do konkretnej prozy Norwidowskiej, gdyż sformułowanie „białe kwiaty cienia” wygląda na parafrazę słów Cypriana Norwida $\mathrm{z}$ prozatorskiego cyklu Białe kwiaty ${ }^{7}$. Na prozę wskazywałoby również kryterium negatywne w postaci braku typowych cech wiersza. Nie wikłając się $\mathrm{w}$ dyskusje szczegółowe, można w uproszczeniu przyjąć, że wiersze identyfikowane są zwykle na podstawie jednego $z$ dwóch wyróżników: albo na podstawie dodatkowej pozaskładniowej delimitacji, albo na podstawie powtarzalności jakiegoś wzorca rytmicznego. W utworze nie ma zaś ani działów pozaskładniowych, ani dwóch analogicznych wersów.

Zanim jednak pochopnie wykluczymy $O$ ! z obszaru wiersza, przywołajmy cenną uwagę, która powinna w porę zdestabilizować zakradające się do tego artykułu powierzchownie opozycyjne rozumienie relacji między wierszem a prozą. Chodzi o błyskotliwą dygresję, poczyniona przez Marię Dłuską w przypisie do rozprawy Wiersz z 1962 roku. W tekście głównym znalazła się teza, którą wszyscy czytelnicy dobrze zapamiętali. Dłuska przekonywała tam, że pewne elementy wersu ujawniają funkcję wierszotwórczą dopiero we współpracy $z$ innymi wersami tego samego utworu. Mało kto zauważył natomiast notkę na marginesie:

Niekiedy jednak [...] jakaś formuła wierszotwórcza na skutek wielokrotnego z nią obcowania wbija się w pamięć i zaczyna stanowić model tak charakterystyczny, że całostkę o tej strukturze napotkaną czy to w izolacji, czy nawet w kontekście prozy odnosi się natychmiast do owego pamięciowego modelu i rozpoznaje jako wiersz ${ }^{8}$.

Trudno byłoby znaleźć lepszy cytat potwierdzający obserwację Dłuskiej niż właśnie utwór Hartwig. Składa się nań przecież 13-zgłoskowa fraza z granicą intonacyjna po sylabie siódmej. Fraza ta zdaje się współbrzmieć $\mathrm{z}$ formułą klasycznego „bohatyrskiego” 13-zgłoskowca (7+6), zmieniając typ naszej uwagi z odbioru prozy na słuchanie wiersza. $Z$ elementów tekstu, które jeszcze chwilę temu wyglądały na prozę, konstytuuje się wiersz.

Warto zaznaczyć, iż O! wpisuje się w tradycję wiersza nie tylko dzięki pozycji, jaką 13-zgłoskowiec wywalczył sobie w literaturze polskiej, ale także za sprawą czynników ułatwiających jego identyfikację. Nie chodzi tu, oczywiście, o świadome stwierdzenie i nazwanie danego formatu wersyfikacyjnego przez odbiorcę, lecz

$6 \quad$ M. Telic ki, Poetycka antropologia Julii Hartwig. Poznań 2009, s. 64.

7 C. Norwid, Białe kwiaty. W: Pisma wybrane. Wybrał i objaśnił J. W. G o mulicki. T. 4: Proza. Warszawa 1968, s. 53: „Takich to c is z akordy straszne są samą głębokością sądnych kombinacji swych, przytoczyłem zaś on powyższy zarys na to, aby białe kwiaty stosowny sobie miały cień $[\ldots] ”$.

8 M. Dłu ska, Wiersz. W: Prace wybrane. T. 1: Odmiany i dzieje wiersza polskiego. Kraków 2001, s. 8, przypis 1 . 
o stworzenie warunków pozwalających usłyszeć dany odcinek tekstu jako przyniesiony przez wiersz. Czytelnik, który nie dokona mimowolnie tej wersologicznej kwalifikacji, nie zrozumie utworu; pozostanie głuchy na jego artystyczne cele. A realizację tych zamierzeń wspierają dwie zasadnicze strategie: jedna - natury rytmicznej; druga - o charakterze intertekstualnym. Pierwsza $z$ nich polega na wypełnieniu wersu tokiem jambicznym. Druga - sprowadza się do użycia w nagłosie samogłoski „O”. O ile nie wymaga dowodu wpływ toku jambicznego na recepcję melodycznych walorów utworu, o tyle znaczenie „O” dla stylu jego lektury oraz kierunków interpretacji stanowi zagadnienie złożone, którego rozpatrzenie zajmie nam resztę artykułu.

Najpierw sprawa podstawowa. Rozpoczęcie wersu od wykrzyknienia nie wynika, wbrew pozorom, jedynie $z$ emocji, ujawnianej przez osobę mówiącą. Rozwiązanie to zostało nazwane operacją intertekstualną, ponieważ właściwa funkcja „O” nie jest definiowana ani przez utwór, ani przez stan uczuciowy autorki, lecz przez tradycję literacką. Tak jak „białe kwiaty cienia” można rozpatrywać na prawach aluzji do prozy Norwida, tak też „O” stanowi swego rodzaju cytat, w którym zostaje przywołany nie tyle konkretny tekst, ile określony wycinek tradycji. Tradycja ta w kulturze współczesnej kojarzona jest przede wszystkim z poezją, często retorycznie nacechowaną, ale pierwotnie, czyli w starożytności, przejawiała się w równej mierze $\mathrm{w}$ wierszu i w prozie. W antyku wykształciły się także podstawowe znaczenie i główne funkcje, jakie w stuleciach późniejszych będą cechowały literackie „O!” Większość pomysłów artystycznych, związanych $z$ tą samogłoską w poezji europejskiej, okaże się wyciagganiem semantycznych konsekwencji z tego, co zostało rozstrzygnięte dawno temu, w literaturze greckiej i łacińskiej.

\section{Pochodzenie}

W języku greckim okresu klasycznego długie „O!”, różnie akcentowane, nosiło na sobie ślady zwyczajów społecznych i religijnych, wywodzących się jeszcze z czasów archaicznych. $Z$ różnych odcieni znaczeniowych, które podaje słownik Henry'ego Liddella i Roberta Scotta, dla badanej historii szczególnie istotne wydaja przede wszystkim dwa ${ }^{9}$.

Po pierwsze, $\tilde{\omega}$ funkcjonowało w attyckiej mowie potocznej jako typowa partykuła poprzedzająca zwrot do adresata, występując zarówno przed imieniem człowieka lub bóstwa, jak i przed antonomazją tego imienia. Według informacji podanej przez Eleanor Dickey, w dialogach dydaktycznych Platona i Ksenofonta „थ̃ jest używane w ponad $90 \%$ apostrof" ${ }^{10}$. Co ciekawe, $\tilde{\omega}$ było też stawiane przed wyrazem

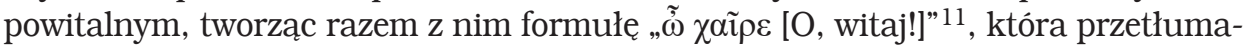
czona na różne języki europejskie dotrwała do naszych czasów. Znajdujemy ją np. w znanych słowach z Ksiegi ubogich Jana Kasprowicza:

„ஸ̃”. Hasło w: A Greek-English Lexicon. Compiled H. G. Li d d e11, R. S c o tt. Oxford 1996, s. 2029.

E. D i c k ey, Latin Forms of Address: From Plautus to Apuleius. Oxford, N. Y., 2002, s. 226.

Autorzy hasła w słowniku A Greek-English Lexicon podają przykład wersu 22 Agamemnona Ajschylosa. 
Witajcie, kochane góry,

O, witaj, droga ma rzeko! ${ }^{12}$

Również Julia Hartwig, zwracająca się do „blasku rzeki” apostrofa „O”, może być zaliczona do spadkobierców tej wielowiekowej tradycji.

Po drugie, w kulturze greckiej długie „O!” było też w jakiś sposób związane $\mathrm{z}$ rytuałem, na co wskazują m.in. fragmenty lamentacyjne tragedii Ajschylosa (Persowie 〈w. 985〉 i Agamemnon (w. 1214)). Gdy poeta chciał wydobyć właśnie to drugie znaczenie, powtarzał naszą samogłoske w serii - 2 lub 3 razy bezpośrednio po sobie - podobnie jak to miało miejsce w wypadku innych onomatopeicznych wykładników rytualnej emocji: żalu, osłupienia, gniewu, z jakimi spotykamy się

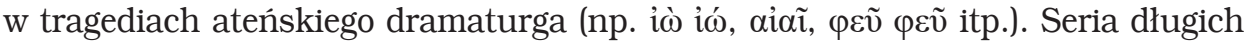
„O!” (w tłumaczeniach na jezzyk polski oddawana zwykle słowami „O, biada”13) rozlegała się w szczytowym momencie widowiska, kiedy ujawniała się z całą dotkliwością nieuchronność wyroków losu. Najciekawszy jednak wydaje się w tym kontekście nie Ajschylos, lecz Sofokles. Warto zwrócić uwagę na dwa zawołania włożone w usta chóru w dramacie Edyp $w$ Kolonie w wersie $224^{14}$. Za drugim razem seria „ڤ̋̀ đ̆” stanowi całą wypowiedź, cały komentarz chóru, wcinający się jak przeciagły jęk w słowa Edypa. Do tych dwóch samogłosek nie zostaje dołączony żaden inny dźwięk. Tak jakby pojemność semantyczna serii „O!” równała się treści kompletnego znaczeniowo zdania.

Dalsza historia samogłoski wiąże się $z$ procesem nabywania przez nią statusu międzynarodowego. Wydaje się znamienne, że nie tylko pierwsze, ale i drugie $z$ rozpatrywanych tu znaczeń, zostało wykorzystane w Septuagincie, czyli starożytnym przekładzie Starego Testamentu na język grecki. Z jednej strony, psalmista zwracał

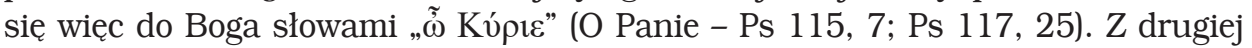
zaś, leksem đ̃ służył do oddania hebrajskich wykrzyknień złorzeczących „oj” (Lb 24, 23) i „hoj” (Zach 11, 17), tłumaczonych w Biblii Tysiaclecia za pomoca wyrazu „biada”. Biorąc pod uwagę zależność Nowego Testamentu od terminologii religijnej przyjętej w Septuagincie ${ }^{15}$, można zatem przypuszczać, że w słowach Jezusa: „O plemię niewierne i przewrotne! Jak długo jeszcze mam być $z$ wami; jak

J. Kas prowicz, Księga ubogich, I, w. 1-2. W: Wybór poezji. Oprac. J. J. Lipski. Wyd. 3, rozszerz. Wrocław 1990, s. 355. BN I 120.

13 Zasadniczo jako polskie ekwiwalenty „ஸ̃” słowniki podają dwa inne wyrazy: „o!” i „och!” Zob. Stownik grecko-polski. Oprac. Z. Abramowiczówna. T. 4. Warszawa 1965, s. 674. - Słownik grecko-polski. Na podst. słownika Z. Węclewskiego oprac. O. J u rewi c z. T. 2. Warszawa 2001, s. 537. Wyraz „biada” stosowany jest jednak systematycznie w przekładach wspomnianych tragedii Ajschylosa. Zob. np. Aj s c hylo s: Agamemnon; Persowie. W: Tragedie. Przeł. Z. W ęcle wski. Poznań 1873, s. 84, 334; Persowie. W: Cztery dramaty. Przeł. J. Kas prowicz. Lwów 1911, s. 100; Persowie. Przeł. K. Kaszews ki. W: Prometeusz skowany. - Persowie. Wstęp, objaśn. S. Witkow s ki. Wrocław 2005, s. 277; Persowie; Agamemnon. W: Tragedie. Przeł., oprac. S. Srebrny. Kraków 2005, s. 144, 410; Persowie. W: Tragedie. Przekł., wstęp, przypisy R. R. Chodkows ki. Lublin 2015, s. 140.

14 Pojedynczy wers 224 jest dzielony na trzy cząstki, wypowiadane kolejno przez chór, Edypa i ponownie chór. W wersach wcześniejszym i późniejszym przemawia Edyp.

15 Zob. E. F. H a r r is o n, The Influence of the Septuagint on the New Testament Vocabulary. „Bibliotheca Sacra”. T. 113 (1956). - T. T. M c L a y, The Use of the Septuagint in New Testament Research. Grand Rapids, Mich., 2003, s. 144-173. 
długo mam was cierpieć” (Mt 17, 17; zob. Mk 9, 19; Łk 9, 41), zlały się w istocie oba greckie znaczenia „O!”

Ich kontaminacja, czyli oparcie apostrofy na tym samym wyrazie, co formuła rytualnej i autorytatywnej przestrogi, może zaskakiwać czytelnika mającego świadomość, że z lingwistycznego punktu widzenia sa one przecież swoimi przeciwieństwami. W wypadku zwrotu do adresata, $\tilde{\omega}$ wykazuje zwiąek $z$ następującymi po nim wyrazem lub frazą, współpracując $z$ nimi w celu uzyskania efektu apostrofy. Kiedy wieszcz Kalchas w pierwszej pieśni Iliady wygłasza słowa „־ А A $\chi \imath \varepsilon \varepsilon \tilde{v}[O$, Achillesie]”, forma wołacza w rzeczowniku jest odpowiedzią na żądanie postawione przez " $\Omega$ ". Analogicznie będzie się zachowywać antonomazja w słynnym cytacie z Jana Kochanowskiego: „O białoskrzydła morska pławaczko” 16 . Tymczasem w znaczeniu drugim, poświadczonym w przywołanych tragediach Ajschylosa i Sofoklesa, status „O!” radykalnie się zmienia. Wykrzyknienie zostaje wyizolowane $z$ otoczenia tekstowego, zamykając się w swego rodzaju semiotycznym kokonie. Częstokroć z eksklamacją nie podejmuje współpracy żaden wyraz w składniowej strukturze tekstu. Różnice te mają tak zasadniczy charakter, że dałoby się mówić od dwóch odrębnych jednostkach leksykalnych, kojarzących się ze sobą wyłącznie za sprawą homonimii.

A przecież cytat $z$ Ewangelii jest tylko jednym $z$ wielu przykładów, kiedy oba sensy zostają na siebie ewidentnie nałożone. Prawdopodobna przyczyną asocjacji wydaje się tu nie tyle podobny dźwięk, ile pewna analogia funkcjonalna. Rola zwrotu do adresata wbrew pozorom nie była zarezerwowana wyłącznie dla znaczenia pierwszego. W wypadku „O!” występującego w znaczeniu drugim wspomniany wcześniej semiotyczny kokon odgrywał bowiem rolę podobną do tej, która Jurij Łotman i Borys Uspienski wskazali jako charakterystyczną cechę imienia własnego ${ }^{17}$. Wygłaszając serię „O!”, zrywało się niejako więzi z resztą tekstu i wychodziło się poza tekst w stronę wyższej instancji, przysłuchującej się wypowiadanym słowom, którą za Michaiłem Bachtinem należałoby nazwać instancją nadadresata ${ }^{18}$. Nieprzypadkowo w tragediach greckich serie „O!” powierzane były chórowi, reprezentującemu widownię znajdująca się poza sfera czasoprzestrzennych relacji bohaterów spektaklu. Kiedy postać w tragedii nie mogła apelować do współczucia widza, traktując go jako adresata, nadal istniał sposób odwołania się do społecznego osądu publiczności, uświadamiającej sobie własny dostęp do sfery nadadresata i dostrzegającej kolektywnie werdykt wydawany przez historię, moralność czy bogów, na który miał prawo liczyć bohater dramatu lub przed którym uciekał.

J. Ko ch ha now ski, Odprawa posłów greckich. W: Dzieła polskie. Oprac. J. Kr zyża n ow ski. Warszawa 1989, s. 599.

17 J. Łotman, B. Uspienski, Mit-imię-kultura. W: B. Uspienski, Historia i semiotyka. Przeł. B. Żyłko. Gdańsk 1998. Zob. też Ü. Pärli, E. Ru dakovs kaj a, Juri Lotman on Proper Name. „Sign Systems Studies” 2002, nr 2, s. 578-584.

18 Pojęciem nadadresata M. B a ch t in posłużył się w artykule Problem tekstu $w$ lingwistyce, filologii $i$ innych naukach humanistycznych. Próba analizy filozoficznej (w: Estetyka twórczości słownej. Przeł. D. Ulicka. Oprac., przekł., wstęp E. Czaplejewicz. Warszawa 1986, s. 436). Zob. G. S. M or s on, C. E m e r s o n, The Superaddressee. W zb.: Mikhail Bakhtin: Creation of a Prosaics. Stanford, Calif., 1990, s. 135-136. 


\section{Adresat i nadadresat}

Ostatecznie więc w postaci obu znaczeń „O!” dostajemy podobne typy relacji w układzie komunikacyjnym, a tylko rozpatrywane na innym poziomie. Był to albo ukierunkowany jawnie zwrot do adresata (np. „ஸ̃ A A $\chi \imath \lambda \varepsilon v$ ”), albo nieukierunkowany jawnie zwrot do nadadresata (np. „ஸ̄ ö”). Żeby uprzystępnić polskiemu czytelnikowi różnicę między tymi poziomami, przywołajmy kilka cytatów z poezji Adama Mickiewicza:

O! luba, zginąłem w niebie,

Kiedym raz pierwszy pocałował ciebie! [w. 326-327 $]^{19}$

Słowa Gustawa z czwartej części Dziadów są, oczywiście, typowym apostroficznym zwrotem do adresata. Tego samego nie można jednak powiedzieć o znanej sentencji z Epilogu:

O, gdybym kiedy dożył tej pociechy,

Żeby te księgi zbłądziły pod strzechy, [w. 107-108] ${ }^{20}$

Poeta nie dzieli się tą myślą z żadną konkretną osobą. Nie znaczy to jednak, że jego słowa padają zupełnie $\mathrm{w}$ próżnię. Wystarczy je porównać $\mathrm{z}$ innym, bardzo podobnym cytatem z utworu Nieznajomej siostrze przyjaciótki mojej:

O! gdyby dozwoliły wyroki łaskawsze

Widzieć tę gwiazdę społem i z bliska, i zawsze! [w. 13-14] ${ }^{21}$

W tym wypadku dowiadujemy się dokładnie, jaka wyższa instancja byłaby w stanie spełnić życzenie wypowiedziane w wierszu. „Wyroki łaskawsze” nie są przy tym wskazanym wprost adresatem monologu. Podmiot utworu przemawia formalnie w stronę kobiety. „Wyroki łaskawsze” należy więc uznać za nadadresata, z którym relację komunikacyjną próbuje się nawiązać drogą nieukierunkowaną jawnie: właśnie za pomoca „O!”

W dwóch ostatnich cytatach odbiorca zawołania jest zatem jakiś nadadresat, mający prerogatywy boskie, które pozwalają upatrywać w nim instancji zdolnej do odwrócenia biegu wydarzeń w sposób niejako nadprzyrodzony. Jest to zarazem tajemniczy uczestnik komunikacji: nie zabiera głosu, nie zostawia po sobie żadnych śladów w utworze, a nadawca nie ma na niego żadnego wpływu. Metafizyczny i metakomunikacyjny status nadadresata domaga się włączania go w przestrzeń wypowiedzi na szczególnych prawach. Rytualne „O!” stanowi zawołanie od wieków specjalizujące się w tej funkcji.

Między słowami Epilogu a fragmentem zamykającym wiersz Nieznajomej siostrze przyjaciótki mojej zachodzi jednakowoż pewna istotna różnica. W obu wypadkach wykrzyknienie zostaje sformułowane ze świadomością obecności nadadresata, lecz tylko w Epilogu nie spełnia ono żadnego dodatkowego zadania. W wierszu Niezna-

19 A. Mickiewi cz, Dziady. CzęśćIV. W: Dramaty. Oprac. Z. St e fa n ow s ka. Fragm. franc. przeł. z rkpsu przez A. Górskiego przejrz. i popr. J. Parvi. Warszawa 1995, s. 57.

20 A. Mickiewicz, Pan Tadeusz. Oprac. Z. J. Nowak. W: Dzieła. Wyd. Rocznicowe. T. 4. Warszawa 1998, s. 386.

21 A. Mickiewicz, Nieznajomej siostrze. Wiersze. Oprac. Cz. Zgorzels ki. W: Dzieła. Wyd. Rocznicowe. T. 1. Warszawa 1993, s. 270. 
jomej siostrze przyjaciótki mojej jest natomiast wypowiadane w dwóch kierunkach naraz. Jako nośnik apelu do nadadresata zastępuje zwrot po imieniu skierowany w stronę instancji wyższej, której to imię, czy raczej antonomazja (,wyroki łaskawsze”), zostaje wyjawione w dalszym ciagu wersu. Zarazem jednak „O!” stanowi także końcowy fragment monologu wygłoszonego do adresatki wiersza, którą we wcześniejszej (niecytowanej) części utworu wskazano zaimkiem „ciebie”.

W rezultacie więc w postaci trzech cytatów z Mickiewicza otrzymujemy - w skrócie - trzy warianty, w których zawiera się literacki potencjał „O!” Samogłoska bywa kierowana albo do adresata (jak w Dziadach), albo do nadadresata (jak w Epilogu), albo w obie strony naraz (jak w utworze Nieznajomej siostrze przyjaciótki mojej). Wydaje się, że spektrum tych możliwości było już w pełni określone na etapie klasycznej poezji greckiej. W momencie przeniesienia centrum kultury literackiej z języka greckiego do łaciny nic się w tej materii nie zmieniło, ujawniła się natomiast nowa warstwa semantyczna, która stała się następnie trwałym elementem tradycji literackiej.

\section{Międzynarodowy leksem poetycki}

Zasadniczo w literaturze łacińskiej odnajdujemy te same dwa podstawowe znaczenia „O!”, które omawialiśmy dotąd. O ile więc Horacy rozpoczyna Pieśń XXX z Księgi Pierwszej wezwaniem „O Venus”, zwracając się do bogini w drugiej osobie, o tyle Cyceron wypowiada swoje słynne „O tempora! O mores!” wobec całego świata i wszelkich możliwych bytów nadprzyrodzonych. Jak jednak zauważyła Dickey, w rzymskiej prozie i komedii zdania poprzedzone wykrzyknieniem „O!” wprowadzały też do dzieła dodatkową aurę: bywały związane także z zamiarem nadania tekstowi posmaku greckiego. Było to szczególnie przydatne wówczas, gdy słowa w utworze miała wypowiadać postać Greka. „O!” wnosiło wtedy do tekstu pewien odcień obcości czy wręcz internacjonalizmu, który w następnych stuleciach i kolejnych literaturach ulegał stopniowemu powiększeniu. Można ująć to tak, że historia poezji europejskiej była świadkiem systematycznego poszerzania i uniwersalizacji tego wyjściowego kręgu skojarzeń.

Kiedy w XIV wieku angielski poeta Geoffrey Chaucer wygłaszał formuły adresowane do bohaterów mitologicznych - w rodzaju: „O Eneas! [O Eneaszu]” ${ }^{22}$, „O Cupide [O Kupidynie]”23, „O god of science and of light, / Apollo [O boże nauki i światła, / Apollonie]” 24 - wówczas jeszcze obsadzał „O” w roli indeksu anonsującego tradycję grecką, zupełnie tak samo, jak czynili to ongiś autorzy łacińscy. Z chwila jednak, gdy posłużył się wyrażeniem „O woful Mars! alas! [O żałosny Marsie! niestety!]"25, zwrot do postaci z rzymskiego panteonu sygnalizował już prawa obowiązujące w epoce nowej, w której pole konotacji łączących się z samogłoską uległo powiększeniu, obejmując teraz nie tylko Grecję, lecz w ogóle cała śródziemnomorską cywilizację antyczną. Decyzja Chaucera nie była przy tym jego indywidualnym

G. Ch a u c er, The Hous of Fame, ks. I. W: Complete Works. Ed. W. W. Ske at. T. 3. New York 2008, s. 10.

G. C h a u c er, The Canterbury Tales. W: Complete Works, t. 4, s. 47.

C h a u c er, The Hous of Fame, ks. III, s. 33.

G. Ch a u c er, The Compleynt of Mars. W: Complete Works, t. 1, s. 327. 
pomysłem, lecz przejawem ogólnej tendencji, która w kulturze europejskiej nadała „O!” charakter jednego z częściej stosowanych środków służących do ewokowania efektu starożytności. Wykorzystał go Jan Kochanowski w Pieśni 22 z Ksiag wtórych, zwracając się do lutni apostrofa „O czci Febowa”26. Lecz znaczenie to wróciło ze zdwojoną siłą $\mathrm{w}$ wieku XIX, kiedy pojęcie starożytności zaczęło być rozumiane w odmienny sposób, wynikajacy z nowoczesnego podejścia do historii. W epoce tej literatura zapełniła się licznymi zwrotami do adresata, typu „O! Kassandro” (Fantazy Juliusza Słowackiego), „O! Plato...” (Plato i Archita Cypriana Norwida), „O Pallas!” (Achilles Stanisława Wyspiańskiego) itp., mającymi sytuować dzieła polskich poetów w kontekście antyku.

W wieku XIX te same cele przyświecały także próbom reaktywacji „O!” w odmianie zwrotu do nadadresata, a szczególnie częste próby imitacji greckich okrzyków lamentacyjnych podejmował w swoich dramatach Słowacki. W utworach poświęconych prapoczątkom narodu polskiego - Balladynie i Lilli Wenedzie - miało to zapewne służyć postawieniu znaku równości między Polską bajeczną, lechicką oraz Grecją czasów antycznych:

ROZA WENEDA

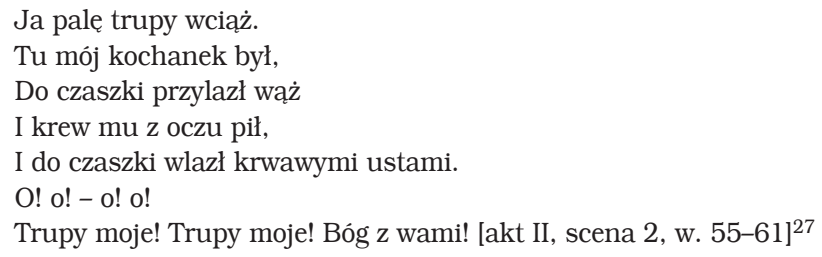

Słowacki jest w ogóle w literaturze polskiej niekwestionowanym rekordzistą, jeśli brać pod uwagę skalę wykorzystania „O!” Wykrzyknienie powtarza się w jego poezji kilkaset razy w najróżniejszych odmianach semantycznych. Łącząc je $z$ wyrazem „biada”, poeta budował aurę kommosu, odgrywanego jednakowoż nie na stokach góry Kitajron, lecz nad Gopłem:

\author{
CHÓR DWUNASTU HARFIARZY \\ O! synu! serce twe $z$ boleści pęknie, \\ O, córko! ojca twego krew cię splami! \\ O! biada wam! o! biada niewolnicy! [akt II, scena 3, w. 365-367] ${ }^{28}$
}

Rozciągnięcie sfery odniesień z Grecji na całą starożytność, które dokonało się $\mathrm{w}$ średniowieczu jako jeden $\mathrm{z}$ aktów założycielskich literatury europejskiej i które w okresie zaborów pozwoliło Słowackiemu symbolicznie włączyć w tę starożytność także prapoczątki Polski, nie było wszakże ostatnim etapem poszerzania konotacji „O!” Za jeszcze dalej idacy krok należy uznać przypisanie tej samogłosce charakteru ogólnie klasycznego. Mickiewicz wołajacy w poemacie Kartofla: „O, Trębeckimi godzien

J. Kochanowski, Pieśni. Oprac. L. Szczerbicka-Ślęk. Wyd. 4, zmien. Wrocław 1998, s. 87. BN I 100.

27 J. Słow a cki, Lilla Weneda. W: Dzieła. Red. J. Krzyża now s ki. Wyd. 2. T. 7: Dramaty. Oprac. M. Grabows ka. Wrocław 1952, s. 320. 
uwielbienia rymy!” (w. 2) ${ }^{29}$, definiował „Trębeckie rymy” jako coś wyniesionego na pozycję literackiego kanonu. Najdalej idącym przekształceniem wydaje się zaś niemal całkowite zerwanie więzi $z$ mowa potoczna, skorelowane $z$ nadaniem samogłosce roli leksemu zrozumiałego wyłącznie w takim języku, który ma charakter zarazem artystyczny i międzynarodowy. „O!” - coraz mniej akceptowane w codziennej komunikacji - zaczęło funkcjonować jako wyróżnik języka poetyckiego, zarezerwowany zasadniczo dla utworów literackich i religijnych, i pojmowany w mniej więcej jednakowy sposób przez różne narody Europy. Polska nie została w tym procesie pominięta. Niepoetyckie „O!” zachowało się w potocznej polszczyźnie jedynie w zleksykalizowanych i wytartych (gdyż pozbawionych sakralnej głębi) reliktach zwrotu do nadadresata, w rodzaju „O nie!” lub „O Boże!” Wszystkie pozostałe użycia „O!” pociagaja za sobą wydźwięk poetycki i są zrozumiałe tylko w ramach międzynarodowej konwencji. Mickiewicz, włączając „O!” w skład wersu, posługiwał się zatem wyrazem pochodzącym nie tyle z języka polskiego, ile ze wspólnego poetyckiego języka Europy.

Cyklowi ewolucyjnemu: greckość - starożytność - klasyczność - poetyckość, towarzyszyło stopniowe zagarnianie „O!” przez mowę wiązaną. Jak już zostało wspomniane na początku artykułu, w kulturze greckiej „O!” nie było przypisane ani do prozy, ani do wiersza. Odpowiedzialność za zmianę tej sytuacji wypada przyznać literaturze łacińskiej. O ile - zgodnie z obliczeniami Dickey ${ }^{30}$ - Cyceron w swoich dziełach prozatorskich poprzedzał eksklamacja zaledwie $2 \%$ wołaczy, a w komediach Plauta i Terencjusza była to skala odpowiednio 4\% i 6\%, o tyle u Owidiusza liczba ta siegała już 9\%, u Wergiliusza - 16\%, a u Enniusza, poety z początkowej fazy literatury lacińskiej, nawet 36\%. Ten wynik (w każdym wypadku o wiele mniejszy niż ponad 90\%, stwierdzone w dialogach dydaktycznych Platona i Ksenofonta) dowodził znacznie słabszej inklinacji języka łacińskiego do posługiwania się omawiana samogłoska jako wykładnikiem apostrofy. Zarazem wszelako był też dowodem zawłaszczenia „O!” przez poezję. W swoim głównym trzonie późniejsza literatura poszła właśnie śladem Enniusza. „O!” można - owszem - spotkać w prozie. Będzie tam jednak zawsze elementem nieprozatorskim, jak gdyby - cytatem $z$ języka poezji. Jęk zachwytu Rafała Olbromskiego na widok Heleny de With - „O, włosy, włosy złote... O, usta, o moje usta...” - pojawia się zatem w powieści Popioły (rozdział Loża profanki ${ }^{31}$ ), czyli w dziele pisanym proza, lecz swoim tonem przypomina raczej fragment wiersza. Do tego stopnia, że dałoby się wskazać pierwowzór wypowiedzi w postaci Sonetu 161 Petrarki (będzie o nim jeszcze mowa). Słowa takie nie mogłyby wystapić w zwykłej, potocznej komunikacji.

\section{Dwa przejawy autonomizacji}

Funkcjonowanie „O!” w roli międzynarodowego leksemu poetyckiego otwierało drogę do operowania jego niezależnością od prawideł języków narodowych i mowy

A. Mi cki i w i c z, Kartofla. Poemko we czterech pieśniach, [Fragment]. W: Poematy. Oprac. W. Floryan przy współpr. K. Górskiego i Cz. Zgorzels ki e go. Warszawa 1994, s. 249.

$30 \quad$ Dickey, op. cit., s. 227.

31 S. Żeromski, Popioły. Oprac. J. Paszek. Wstęp, bibliografia I. Maciejewska. Koment. A. Achmatowicz. T. 1. Wrocław 1996, s. 443. BN I 289. 
prozatorskiej. „O!” nie tylko zachowało swój semiotyczny kokon, który przyswoiło sobie na gruncie greckich rytuałów religijnych, ale wykształciło z czasem dodatkowe środki podkreślające jego autonomię. Najdalej idące rozstrzygnięcia nie miały w ogóle charakteru językowego, dlatego wypada zacząć właśnie od nich.

W wiekach średnich „O!” stało się bardzo częstym elementem inwokacji do Boga na początku modlitwy, co zachowało się do dziś w języku angielskim. Wystarczy przekartkować The Book of Common Prayer, by zdać sobie sprawę z powszechności sformułowan typu: „O Almighty God”, „O holy, blessed, and glorious Trinity, one God”, „O God, Creator of heaven and earth” itp. ${ }^{32} \mathrm{~W}$ liturgii łacińskiej wysoka pozycję wysłużyły sobie tzw. Antyfony „O”, czyli 7 antyfon do maryjnego kantyku Magnificat, rozpoczynające się kolejno od wykrzyknień: „O Sapientia [O Mądrości]”, „O Adonai [O Panie]”, „O Radix Jesse [O Różdżko Jessego]”, „O Clavis David [O Kluczu Dawida]”, „O Oriens [O Wschodzie]”, „O Rex Gentium [O Królu Narodów]”, „O Emmanuel [O Emanuelu]”. Antyfony, mające za autora - według tradycji - Grzegorza Wielkiego i odmawiane przez 7 ostatnich dni Adwentu, obrosły w Europie Zachodniej własnym kontekstem kulturowym. Na Półwyspie Iberyjskim istniał zwyczaj erygowania kościołów pod wezwaniem Najświętszej Marii Panny od O (np. Iglesia de Nuestra Señora de la $\mathrm{O}$ w Sewilli). Stosownie do treści Magnificat, okres śpiewania Antyfon „O” łączono z działalnością charytatywną, wokół której rozwinął się wielobarwny folklor. Warto tu wspomnieć o Święcie Słodkiego O, od niepamiętnych czasów organizowanym przez handlarzy wina w klasztorze Saint-Germain w Paryżu ${ }^{33}$. Jak zaświadcza przewodnik $z$ epoki ${ }^{34}$, zabawa ta była praktykowana jeszcze w połowie XVIII wieku, zanim zmiotła ją rewolucja ${ }^{35}$. Nazwę święta należy wywodzić z gry słów: l'o sucré ('słodkie o') brzmi tak samo jak l'eau sucrée ('słodka woda' lub - jak kto woli - 'słodki trunek'). Oczywiście, Hartwig mogła o tych zwyczajach zupełnie nie wiedzieć. Pozostaje wszelako faktem, że jej utwór ustawia się w długim szeregu dzieł i przedsięwzięć powstałych na cześć „O!”

Innym sposobem wyzyskiwania autonomii „O!”, który także bierze swe początki w średniowieczu, było komponowanie modlitw polegających na wypowiadaniu już nie tylko jednego wezwania, typu „O Radix Jesse”, lecz całej serii tytułów Boga lub Maryi $z$ anafora „O!” Wchodzą tu w grę zarówno teksty skomponowane rytmiczna prozą (np. Oratio ad eamdem sanctam virginem Mariam Anzlema $z$ Carterbury ${ }^{36}$ czy późniejsza Oratio de nomine Iesu, uznawana za dzieło Bernardyna ze Sieny ${ }^{37}$ ),

The Book of Common Prayer and and Administration of the Sacraments and Other Rites and Ceremonies of the Church: Together with The Psalter or Psalms of David: According to the use of The Episcopal Church. New York 2007, s. 148, 152-154, 167 n.

Zob. H. Sauval, Histoire et recherches des antiquités de la ville de Paris. T. 2. Paris 1724, s. 619-620.

Zob. J.-A. Piganiol de La F or ce, Description de Paris, de Versailles, de Marly, de S. Cloud, de Fontainebleau, et de toutes les autres belles maisons et châteaux des environs de Paris. T. 3. Paris 1742, s. 509-510.

Zob. Les $O$ de l'Avent. „Église d'Albi: la semaine religieuse de l'Archidiocèse d'Albi” 1897, nr 51, s. 803.

Zob. Patrologiae Cursus Completus. Series Latina. Éd. J.-P. Mign e. T. 158. Paris 1864, s. 961-962. Zob. D. Pa c e t ti, Gli scritti di San Bernardino da Siena. W zb.: S. Bernardino da Siena: Saggi e ricerche pubblicati nel quinto centenario della morte (1444-1944). Milano 1945, s. 63. 
jak i wyjątkowo interesujące pieśni pisane wierszem sylabicznym. Jeden $z$ takich litanijnych utworów Gilles Gérard Meersseman wynotował z pewnego kodeksu paryskiego. Wiersz pochodzacy z końca XII wieku, adresowany do Matki Bożej i opatrzony nagłówkiem Invocatio cum laude, rozpoczyna się tak:

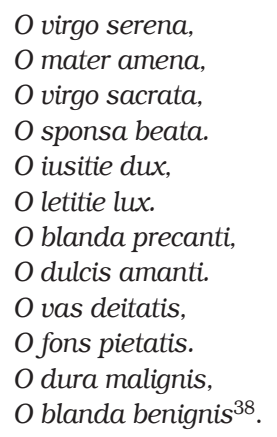

Tekst stwarza pozory dość mechanicznego połączenia ze sobą formuł polegających na użyciu „O” w najprostszej funkcji zwrotu do adresata. Wrażenie to można usprawiedliwić, wysuwając przypuszczenie, że w kodeksie paryskim zostały zanotowane wyłącznie refreny z pominięciem rozdzielających je zwrotek. Wniosek ten pojawia się przy zestawieniu przytoczonego wiersza z pieśnią Edmunda $z$ Canterbury, stanowiącą środkową część Psalterium beatae Mariae Virginae z XIII wieku i cytowaną również przez Meerssemana. W tej drugiej pieśni każda z 50 kwartyn zaczyna się od „Ave [Witaj]”, a po zwrotce udzielana jest zawsze odpowiedź w postaci krótkiej frazy z inicjalnym „O”. Zestawienie „Ave” i „O” należy interpretować

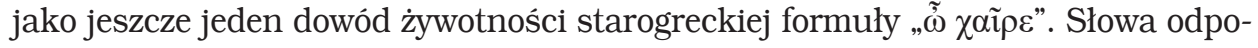
wiedzi pokrywają się zaś z przytoczonymi wcześniej wersami z kodeksu paryskiego:

\footnotetext{
Ave, mitis oliva gratie,

Lenis mater misericordie.

Tu fomentum, tu salus populi.

Tu lucerna totius seculi.

O virgo serena!

Ave, parens unius filii.

Guem non tinxit fex ulla vitii.

Omnis vivens peccato paruit.

Solus iste reatu caruit.

O mater amena!

Ave, virgo verbi puerpera.

Nos in Christi virtute libera.
}

Cyt. za: G. G. M e e r s s e m a n, Der Hymnos Akathistos im Abendland. T. 1. Freiburg 1958, s. 185. Przekład roboczy: „O, dziewico czysta, / O, matko powabna, / O, dziewico uświęcona, / O, oblubienico błogosławiona, / O, przewodniczko sprawiedliwości, / O, blasku radości, / O, przyjazna proszącemu, / O, słodka miłującemu, / O, naczynie bóstwa, / O, źródło pobożności, / O, sroga nikczemnym, / O, przyjazna prawnym". W edycji Meerssemana wezwania łączone są w pary. Zarówno układ rymów, jak i analiza, którą przedstawiamy, porównując ten wiersz z pieśnią zanotowaną w Psatterzu świętego Edmunda, wskazują wszelako, że każde wezwanie należy traktować jako niezależny wers. 


\section{Deum placa sacro precamine, Ut nos salvet in suo nomine. \\ O virgo sacrata! \\ Ave, virgo, que degens celitus Elongasti mundanos strepitus. \\ Domi sanctum agebas otium, Cum celestem audisti nuntium. O sponsa beata ${ }^{39}$.}

Rozstrzygnięcia dotyczące przepływu konwencji w średniowieczu są zawsze bardzo trudne i ryzykowne. Istnieja wszelako przesłanki wskazujące, że cytowana wcześniej wersja $z$ kodeksu paryskiego nie była (lub nie była wyłącznie) indeksem refrenów do pieśni Edmunda $z$ Canterbury, sporządzonym w celach pomocniczych, lecz stanowiła integralnie pomyślaną całość kompozycyjną, mająca funkcjonować albo jako niezależny utwór, albo jako wyróżniający się aspekt strukturalny psałterza. Wynika to nie tyle $z$ wcześniejszej daty spisania tekstu, ile przede wszystkim - z jego głębokiej spójności. Pieśn w kodeksie paryskim ma strukturę dwuwymiarową: poziomy ciag addytywnie dołączanych wersów przecinaja pionowe relacje między wyrazami ustawianymi w paralelnych pozycjach. Po prawej stronie rym, w środku analogiczne części mowy, w nagłosie „O”. Celem tej operacji jest odebranie autonomii poszczególnym wersom i wpasowanie ich w ogólny projekt kompozycyjny, w którym wypowiedź rozwija się wielotorowo: zarówno w logicznym ciagu horyzontalnym, jak i na zasadzie asocjacji wertykalnych. Dla słuchacza kolejne powtórzenia „O" będą więc stanowiły nawroty jednego $\mathrm{z}$ pionowych tematów, nadając „O” charakter jak gdyby niezależnego głosu. „O”, które wydawało się mechaniczną realizacją zwrotu do adresata, odzyskuje w ten sposób autonomię, a w ślad za tym ewokuje swoje drugie znaczenie: zwrotu do nadadresata.

\section{Wkład Petrarki}

Zauważalnie częste użycie „O!” w anaforach łacińskiej poezji średniowiecza nie przełożyło się automatycznie na równie wysoką frekwencję w literaturze języków od łaciny derywowanych. „O!” znajdujemy wprawdzie w najstarszych zabytkach literatury starofrancuskiej - jak choćby kilka eksklamacji typu „O bele boche, bels vis, bele faiture [O, piękne usta, piękne lica, piękna posturo]" w pochodzacym z XI wieku Żywocie świętego Aleksego ${ }^{40}$ - lecz czołowi truwerzy nie widzieli potrzeby mnożenia tego rodzaju wykrzyknień. Gautier de Coincy, zwracając się do Maryi, mówił po prostu „Douce Dame [Słodka Pani]”, nie poprzedzając tej apostrofy osobnym wyrazem eksklamacyjnym. Dla wyrażenia silnej emocji miał raczej inne sposoby, takie jak seria „Las! las! las! las! plus de cent foiz! [Niestety, niestety, niestety, niestety! po stokroć więcej!]" ${ }^{1}$ w grupie pieśni o św. Teofilu z Adany. Również Rutebeuf i Huon le Roi, którzy włączali do swoich utworów wtręty panegiryczno-

La Vie de saint Alexis: poème du XIe siècle et renouvellements des XIIe, XIIIe et XIV siècles. Publ. avec préfaces, variantes, notes et glossaire par G. Paris, L. Pa nnie r. Paris 1872, s. 163.

41

G. de C o in cy, Les Miracles de la Sainte-Vierge. Publ. par A. E. P o qu et. Genève 1972, s. 46. 
-hymniczne na cześć litery „o”42, do wykrzyknień woleli używać innych wyrazów, takich jak „Ahi! Ahi!” u Rutebeufa ${ }^{43}$. Podobne tendencje było widać w poezji prowansalskiej, np. u Peire’a Cardenala, który także unikał „O!”

Można przeto postawić tezę, że ostateczne przeniesienie „O!” do poezji w językach narodowych, powiąanie go z tematyką świecką oraz przynajmniej częściowe uwolnienie od skojarzeń z poezją kościelną - dokonało się dopiero za przykładem Francesca Petrarki. Przełomowe znaczenie będzie tu miał jego Sonet 161, w którym „o” lub „oï otwiera aż 9 wersów:

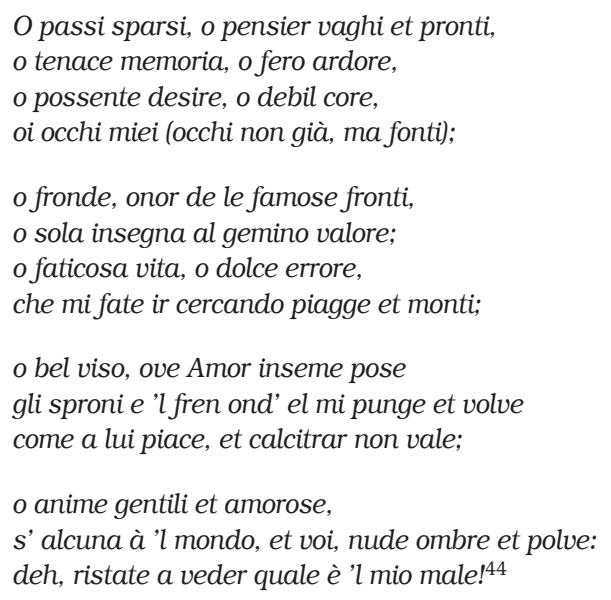

Kolejne „o” i „oi”, po których następują rzeczowniki z epitetami, bardzo przypominają wcześniej cytowaną średniowieczną litanię $z$ kodeksu paryskiego, $z$ tą różnica, że litania została teraz wpasowana w ramy sonetu, a tematyka religijna - zastąpiona przez tematykę miłosną. Zastąpiona - choć nie wyparta, ponieważ istota retorycznego zamysłu polega tu, jak się zdaje, na zachowaniu, dzięki gatunkowi litanii, pamięci o religijnym kontekście, co pozwala przyoblec bohaterkę wiersza w nimb swoistej sakralizacji. Petrarka inną drogą osiagnął podobny efekt, do którego dążył również Dante, umieszczając swoją Beatrycze w raju.

Zob. Ru te b e uf, Le Diz des Cordeliels. W: OEuvres complètes. Recueilles [...] par A. J u bi nal. T. 1. Paris 1900, s. 216-217. - H. Le Roi, Li Abecés par ekivoche et li significations des lettres. W: Obras completas. Estudio, anotaciones y traducción de M. G. Ríos Guardiola. Murcia 2011, s. 92.

Ru t e b e u f, Li diz de maître Guillaume de Saint-Amour... W: CEuvres complètes, s. 94.

Petrarch [F. Petra rk a], 161. W: The Canzoniere, or Rerum vulgarium fragmenta. Trans. into verse with notes and commentary by M. Musa. Introd. ..., B. Manfredi. Bloomington, Ind., 1999, s. 252-253. Jeden z polskich tłumaczy Sonetów do Laury F. Pet r a r k i, J. K u r e k (Kraków 1975, s. 45) przełożył ten wiersz następująco: „O nadaremne kroki! Myśli błędne! / O mocna żądzo! O serce w rozpaczy! / Czujna pamięci! Zapały namiętne! / Oczy me! Już nie oczy - źródła płaczu! // Laurze! Ty Laury mej symbolem będziesz, / Podwójny znaku męstwa i wielkości! / O ciężkie życie! Rozkoszny obłędzie, / Przez ciebie z bólu łkam, ginę z radości! // O twarzy śliczna! W której miłość chowa / Pokusę równie jak i zakaz twardy; / W miarę zachcenia tkliwa lub surowa. // Dusze szlachetne, które miłość znacie, / Żywe i wsiąkłe w pusty proch umarłych, / Przystańcie chwilę, na mój ból popatrzcie”. 
Za życia Petrarki sonet $z$ anafora „o” napisał także Giovanni Boccaccio ${ }^{45}$. Jednakże to właśnie cytowany Sonet 161 okazał się przedmiotem zachwytu i rywalizacji poetów włoskich XV i XVI wieku (wśród nich znalazł się m.in. Ludovico Ariosto ${ }^{46}$ ), do których w wieku XVI i XVII dołączyła niezliczona ilość poetów francuskich ( $\mathrm{z}$ bardziej znanych byli to np. Clément Marot, Pierre de Ronsard i Jean-Antoine de Baï ${ }^{47}$ ). I choć grupę tę powiększyli także poeci reprezentujący inne literatury, to jednak główny front współzawodnictwa $z$ Petrarką sytuował się właśnie we Włoszech i Francji ${ }^{48}$.

Polska literatura strukturę Sonetu 161 bardzo długo lekceważyła. Jak wynika z zestawienia bibliograficznego, jako pierwszy próbę jego translacji podjął dopiero Felicjan Faleński, poeta tworzacy w drugiej połowie XIX wieku i autor bardzo niedokładnego przekładu Canzoniere ${ }^{49}$. W Sonecie 128 (odpowiadającym numerowi 161 u Petrarki) Faleński tylko jeden raz użył wykrzyknienia „O!”, pozbawiając utwór oryginalnej litanijnej struktury. Podskórnie jednak pamięć o włoskim pierwowzorze była w literaturze polskiej wyczuwalna. Z Sonetu 161 przyswojono przede wszystkim charakterystyczny status ontologiczny głównej bohaterki, która jest prezentowana jako nieobecna i do której poeta może się zbliżyć jedynie we wspomnieniach i wyobrażeniach. Zapamiętano, że postacie takie należy opisywać, posługując się wykrzyknieniem, zaś „O!” - w tradycji klasycznej otwierające tekst na metakomunikacyjna figurę nadadresata - znakomicie nadawało się do portretowania osób w danej chwili niedostępnych. Nie tylko zresztą osób, lecz także stanu przyrody, którego nie można przywrócić; wydarzeń, których nie da się ponownie przeżyć; pięknego widoku, który umyka nam sprzed oczu itd. Znać było to petrarkowskie podglebie w szepcie Olbromskiego na widok Heleny de With. Wyczuwa się je również w następującym cytacie z Balladyny:

\section{FILON}

O! złote słońce! drzewa ukochane! O! ty strumieniu, który po kamykach

Z płaczącym szumem toczysz fale śklane! [akt I, scena 1, w. 173-175] $]^{50}$

Mowa tu - formalnie rzecz biorąc - o czym innym niż u Petrarki. A jednak w ustach postaci, stylizowanej na bohatera literatury sentymentalnej, „O!” wygła-

G. B o c c a c ci i, Rime, cz. 2, wiersz 2. W: Tutte le opere. A cura di V. B r a n ca. T. 5, cz. 1. Milano 1992 , s. 98.

L. Ariost o, XXIV. W: Opere. A cura di M. Sant or o. T. 3. Torino 1989, s. 230.

Zob. C. Ma r ot, Six sonnets de Petrarque. W: OEuvres. Éd. rev., augm. Preface N. Le nglet du Fre s no y. La Haye 1731. T. 3, s. 157. - P. de Ron s a d: LIV; CLXXVIII. W: CEuvres complètes. Éd. établie, presentée et annotée par J. Céard, D. Mén a ger, M. Simonin. T. 1. Paris 1993, s. 51-52, 118. - J. A. de Baïf, XLIV. W: Les Amours de Francine. Sonnets. Éd. critique par E. Caldarini. Genève-Paris 1966, s. 193.

Na temat litanii „O!” inspirowanych Petrarką piszę więcej w książce: W. S a d ow ski, European Litanic Verse: A Different Space-Time. Berlin 2018, s. 619-624 (w druku).

M. Gurgul, A. Klimkiewicz, J. Miszalska i M. Woźniak w publikacji Polskie przekłady włoskiej poezji lirycznej od czasów najdawniejszych do 2002 roku. Zarys historyczny i bibliograficzny (Kraków 2003, s. 237) wymieniają tylko dwóch tłumaczy Sonetu 161: F. Faleńskiego i J. Kurka.

J. Słow a cki, Balladyna. W: Dzieła, s. 19. 
szane przed rzeczownikami wyposażonymi w epitety pozwala sobie przypomnieć o toskańskiej lirze. Warto też w tym kontekście przywołać utwór Miłość Krzysztofa Kamila Baczyńskiego. Poeta ten, zamiast przetłumaczyć wiersz Petrarki, postanowił go jak gdyby swoimi słowami opowiedziećc1 ${ }^{5}$ Śladem naprowadzającym na praźródło są jednak „O” i „o” w dwóch początkowych wersach:

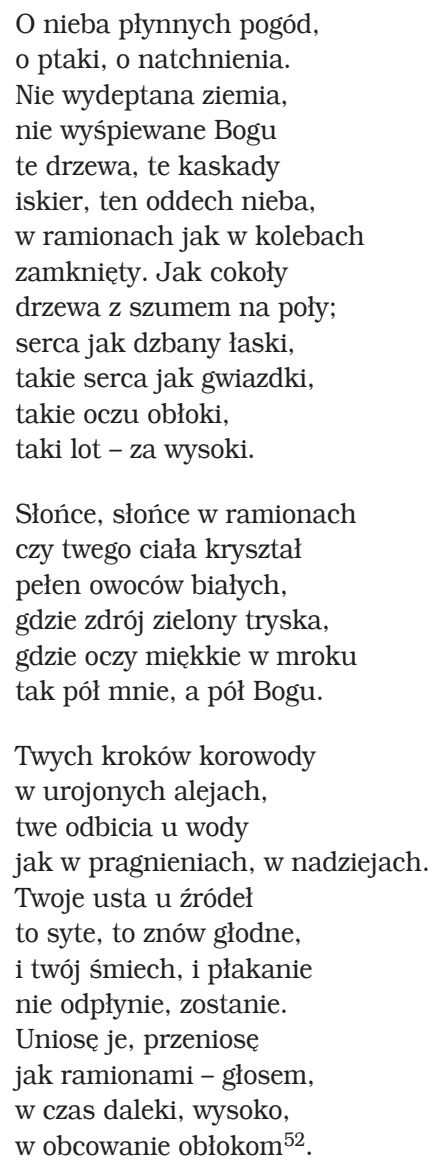

To nie jest jeszcze koniec utworu Baczyńskiego, gdyż na samym dole pojawia się data, która subtelny rysunek adresatki, szkicowany petrarkowską pastelą, wyjmuje z metafizycznego wymiaru wyobrażeń i wspomnień, sprowadzając go brutalnie w realny wymiar sytuacyjny: 8 września 1942 - sam środek hitlerowskiej okupacji.

Przykłady te pokazuja, że Sonet 161 był odbierany w polskiej kulturze jako wiersz na tyle wyrazisty, że przywołanie go czy wejście $z$ nim w dialog nie wymaga

51 Nieoczywisty i głęboko idiomatyczny charakter tego przekładu sprawił zapewne, że utwór Baczyńskiego nie został odnotowany w bardzo pomocnym opracowaniu bibliograficznym polskich przekładów włoskiej liryki (Gurgul, Klimkiewicz, Misztalska, Woźniak, op. cit.).

52 K. K. Baczyń s ki, Utwory zebrane. Oprac. A. Kmita-Pi or un ow a, K. Wy ka. Kraków 1961, s. $287-288$. 
rozbudowanych zabiegów. Kto wie? Może z tej prawidłowości korzysta także utwór Hartwig, w którym - poza „O” - nie ma ani jednego słowa wziętego od Petrarki? Treść wiersza skupia się przecież wokół dwóch opozycyjnie zestawionych danych wrażeniowych „cienia” i „blasku”. Te zaś wcale nie muszą być elementami bezpośredniej obserwacji, ale przeniesione piętro wyżej w przestrzeń mowy poetyckiej ewokują inny wymiar bytu, którego naturę może znać jedynie bezimienny nadadresat. Subtelna, lecz przy tym nie dająca się zlekceważyć, sugestia oddzielania światła od ciemności zdaje się naprowadzać na taką hipertekstualną lekturę.

\title{
Trzeci przejaw autonomizacji
}

Powiedzieliśmy do tej pory o dwóch sposobach wydobywania metakomunikacyjnej autonomii. Jeden $z$ nich polegał na wyprowadzaniu „O!” poza mowę przez umieszczanie go w sakralnej czasoprzestrzeni kojarzonych z nim świątyń i świąt. Drugi na wysuwaniu „O!” do anafory, a więc - na przyznawaniu mu w strukturze wersu pozycji inicjalnej, analogicznej do tej, którą litanie kościelne rezerwują dla imion Boga i świętych. W obu wypadkach w różnych wytworach kultury potwierdzała się ta sama pamięć o rytualnym rodowodzie samogłoski. „O!” było traktowane jako element wzięty $z$ innego słownika, rządzący się swoimi prawami i otwierający drogę do innych światów. Poza tymi dwoma sposobami można jednak mówić jeszcze o trzecim - dość rzadko spotykanym - lecz wyjątkowo istotnym dla poezji, gdyż nieosiaggalnym w prozie. W tym wypadku chodzić będzie o sytuację, w której „O!” bywa lokowane na granicy wersów, jak np. we fragmencie młodzieńczego wiersza Friedricha Hölderlina:

\author{
O ihr Menschen! o so gerne wollt' ich euch \\ Alle lieben, warm und treu! oh ihr Menschen \\ Sehet diese Stella haßt ihr! \\ Gott vergebe es euch! \\ Reißt sie nur hinweg von mir! Quäler! ihr! \\ Ich will schweigen - Gott - Gott wird reden \\ Lebe wohl-ich sterbe bald - $O$ \\ Stella! Stella vergiß mich ${ }^{53}$.
}

W juweniliach Hölderlin bardzo chętnie korzystał z tej samogłoski. Można powiedzieć: bawił się nią w rozmaitych kontekstach. W cytowanym urywku jej nadmiar wydaje się nawet przejawem młodzieńczej egzaltacji, egocentrycznie skupionej na własnych emocjach, z której poeta wycofał się w wieku dojrzałym, redukując wykrzyknienia do wyjątkowych, głęboko przemyślanych momentów. Podobna rozwaga cechowała zreszta pozostałych klasyków weimarskich. Nie zmienia to jednak faktu, że „O” zostało wprowadzone do wiersza w sposób bardzo ciekawy. Utwór wypełniają opętańcze i wzajemnie sprzeczne eksklamacje do różnych adresatów.

F. Höld e r 1 in, Klagen. An Stella, w. 5-12. W: Sämtliche Werke. Hrsg. F. B e i s s n e r. T. 1, cz. 1. Stuttgart 1946, s. 26. Przekład roboczy: „O wy, ludzie! o, jak bardzo was pragnę / Wszystkich kochać, bliscy i wierni! o wy, ludzie, / Zobaczcie, jak Stella was nienawidzi! / Bóg to wam wybaczy! // Zabierzcie ją tylko precz ode mnie! Dręczyciele! wy! / Chcę milczeć - Bóg - Bóg będzie mówił / Bywaj zdrowa - umieram - O / Stello! Stello, zapomnij o mnie". 
Pierwsze „O” jest kierowane do „ludzi”. Drugie - wystrzelone w kosmos. W rezultacie, gdy pojawia się po raz kolejny w przedostatnim wersie cytatu - nie wiadomo, $\mathrm{w}$ jakiej roli wystapi. W tym momencie na granicy wersów otwiera się i niejako zastyga na krawędzi krystalizacji cała tradycja literacka związana z tym dźwiękiem. Czegoś podobnego nie sposób wypracować w prozie.

W literaturze polskiej pokrewny przykład znajduje się $\mathrm{w}$ jednym $\mathrm{z}$ utworów Józefa Czechowicza. Warto przypomnieć, że poeta ten w ogóle szeroko wyzyskiwał instrumentacyjne walory samogłoski $o$, nie tylko eksklamacyjnej, lecz także jako elementu różnych wyrazów składających się na tekst. W utworach prowincja noc i przez kresy wysoka frekwencja o służy kumulowaniu nastroju monotonii, jak również pewnej kolistej powtarzalności. W innym wierszu, zatytułowanym śmierć, czytamy „o koła których 8”54. W utworze pieśń do wymienionych znaczeń dochodzi wszelako jeszcze jedno. Już w pierwszych wersach tekstu znajdujemy „o” w apostrofie:

wieczorze seledynowy łuku pachnacy o wieczorze jaskółek ${ }^{55}$

Kilka wersów dalej apostrofa powraca, lecz zostaje wewnętrznie rozłamana przez podział na dwie linijki druku:

0

pachnący wieczorze podaj dłoń

Podobne zjawisko zachodzi także pod koniec utworu:

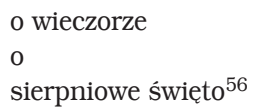

Komentując przytoczone fragmenty, warto wziąć pod uwagę, że zostały one sformułowane w tzw. wierszu wolnym, który w odróżnieniu od wiersza metrycznego nie opiera się na dźwiękowej powtarzalności i w związku z tym jedynym gwarantem jego struktury pozostaje forma graficzna. W recytacji wprowadzone do tekstu zabiegi delimitacyjne mogą okazać się zatem nieuchwytne. Ich rozpoznanie wymaga w tej sytuacji lektury wizualnej. A skoro czytelnik widzi budowę utworu na papierze, trudno podejrzewać, by nie zdawał sobie sprawy, w jakiej roli wystapi ostatecznie „O”, zapisane w izolowanej linijce. Odbiorca, ogarniający wzrokiem więcej niż ten jeden wyraz, dostrzega, że wykrzyknienie okaże się za chwilę inicjalnym elementem zwrotu do adresata - „pachnacego wieczoru” lub „sierpniowego święta”. Czytelnik wie o tym niejako $\mathrm{z}$ góry. I właśnie dlatego ma świadomość zgrzytu polegającego na tym, że „O”, z jednej strony, łączy się z dalszym ciagiem tekstu na poziomie składni, lecz - z drugiej strony - nie chce się z nim połączyć na poziomie zapisu, demonstrując niezależność od reszty wypowiedzi, a dzięki temu wskrzeszając także swoją drugą funkcję: zwrotu do nadadresata.

J. Czechowicz, Przez kresy. Wybór wierszy i przekładów. Wybór P. Szewc. Przedm. Cz. Miłosz. Kraków 1994, s. 76. 


\section{Wiersz Julii Hartwig}

Tak oto dochodzimy ponownie do wiersza Hartwig, od którego zaczął się artykuł. Jest to wiersz, mimo że składa się $z$ jednego wersu. Zarówno forma wierszowa, jak i brak dalszych wersów są dla jego interpretacji parametrem podstawowym, ponieważ tekst zdaje się przenosić uwagę odbiorcy w sferę tego, co nie wypowiedziane. Nie wypowiedziane, bo znajdujące odgłos w tradycji literackiej, która przechowuje w swoich zasobach pamięć o niepoliczonej masie jednostek $\mathrm{z}$ owym wersem ekwiwalentnych. Ale też nie wypowiedziane, bo niewypowiadalne. Bez tego wersyfikacyjnego parametru nie sposób właściwie zrozumieć funkcji „O” w tym utworze. Postawione w nagłosie pojedynczego wersu, występuje ono ewidentnie w roli zwrotu do adresata - „kwiatów cienia” i „blasku rzeki”. Podobnie jednak, jak w przykładach z Hölderlina i Czechowicza, nie jest to w tekście jedyne „O”. Mamy przecież jego drugie użycie: tym razem w tytule. Tytuł nie jest zaś nigdy zwyczajnym elementem wiersza. Należy do sfery paratekstu i zwykle nie uczestniczy w realizacji wzorca metrycznego. Czytamy go w połączeniu $\mathrm{z}$ utworem, a równocześnie - w izolacji. Tytuł stanowi pierwszy etap lektury i zarazem synekdochę tekstu: reprezentuje utwór na zewnątrz. W spisie treści znajdziemy zatem tylko O! - dźwięk ewokujący omówione i nieomówione w artykule konteksty tradycji kulturowej. Ten tytuł nie pojawia się we wszystkich wydaniach utworu. Być może, w przekonaniu samej poetki nie był wcale konieczny. Niewykluczone, że w momencie pierwodruku autorka nie miała jeszcze pewności, czy chce się posługiwać tak uderzajacym efektem artystycznym. Na zmianę decyzji mógł wpłynać wydany 20 lat później tomik to Czesława Miłosza. W jego zbiorze od początku występował utwór zatytułowany O!, a zaraz po nim tryptyk ekfraz o tytułach zaczynajacych sie od „O”57. W spisie treści odpowiadała im zatem lista 4 tytułów $\mathrm{z}$ inicjalnym „O”, przypominająca omawiany tu wcześniej średniowieczny indeks refrenów ${ }^{58}$.

Identyczność tytułów u Miłosza i Hartwig może nie być przypadkowa, gdyż łączy je wspólny cel. Tytuł - związany z utworem i zarazem odrywający się od niego - pozwala mocniej wyeksponować fakt, że również „O!” odrywa się od tekstu, od jezzyka, od wyznaczanych w tym języku, bezpośrednich, zgramatykalizowanych relacji komunikacyjnych. W wierszu Hartwig „O!” zwraca się więc nie tylko do „kwiatów cienia” i „blasku rzeki”, lecz wypowiadane w izolacji, przywodzi na myśl starogreckie okrzyki rytualne, litanie z anafora „O!”, antyfony do Magnificat. Krótko mówiąc: obiecuje relację komunikacyjną $\mathrm{z}$ nadadresatem.

Kim jest ów nadadresat - nie zostało przez Hartwig wysłowione. Nie ma przecież innych wersów, które ujawniłyby jego imię ${ }^{59}$.

Cz. Miłosz, to. Kraków 2000, s. 18-21. Przedruk w: Cz. Miłosz, Wiersze wszystkie. Wyd. 2, uzup. Kraków 2015, s. 1174-1177.

Dziękuję anonimowemu Recenzentowi „Pamiętnika Literackiego” za skierowanie mojej uwagi na argument z poezji Miłosza.

Czytelnicy wyczuwający sakralną wymowę tego chwytu, zgodzą się zapewne, że do utworu można odnieść opinię, wyrażoną przez M. F la k o w i c z - S z c z y r b ę w książce Dowód na istnienie. Poezja Julii Hartwig wobec egzystencji i sztuki (Warszawa 2014, s. 328): „prawdziwa afirmacja bytu łączy się z postawą religijną, która [...] pozwala [...] dostrzec niezwykłą urodę świata, poszukiwać sacrum, przede wszystkim w "cudowności" natury, by rzec "O, jakże cudowny czysty odnowiony dzień!" (Letni poranek)". 
Abstract

WITOLD SADOWSKI University of Warsaw

\section{A SHORT HISTORY OF "Ol” (AROUND JULIA HARTWIG'S POEM)}

The paper presents the main evolutionary stages of the exclamation "O!" in European poetry from antiquity to modern times. A pretext for the research is Julia Hartwig"s poem "O!" in which "O" is both an initial element of the proper text and the sole word in the title. However, the article can also be read otherwise, in which case the analysis of Hartwig's $O$ ! is considered as the main topic whereas the repertoire of meanings and functions of "O", as preserved in the literary tradition, serves as its pre-text. Semantic variants of "O!" in Greek and Latin literature are also indicated and seen as variants derived from a division into two functions, namely an appeal to the addressee, and an appeal to the superaddressee. Next follows an outline of a process through which autonomy from national languages was granted to "O!," thanks to which the word became an international lexeme of poetic language. The illustrative material is taken from English, French, German, Italian, Polish, and Provençal literatures. 